\title{
Disinfection Byproducts in Drinking Water and Evaluation of Potential Health Risks of Long-Term Exposure in Nigeria
}

\author{
Nsikak U. Benson, Oyeronke A. Akintokun, and Adebusayo E. Adedapo \\ Analytical and Environmental Chemistry Unit, Department of Chemistry, Covenant University, Km 10 Idiroko Road, Ota, Nigeria \\ Correspondence should be addressed to Nsikak U. Benson; nbenson@covenantuniversity.edu.ng
}

Received 8 December 2016; Revised 26 May 2017; Accepted 6 July 2017; Published 16 August 2017

Academic Editor: Pam R. Factor-Litvak

Copyright (C) 2017 Nsikak U. Benson et al. This is an open access article distributed under the Creative Commons Attribution License, which permits unrestricted use, distribution, and reproduction in any medium, provided the original work is properly cited.

Levels of trihalomethanes (THMs) in drinking water from water treatment plants (WTPs) in Nigeria were studied using a gas chromatograph (GC Agilent 7890A with autosampler Agilent 7683B) equipped with electron capture detector (ECD). The mean concentrations of the trihalomethanes ranged from zero in raw water samples to $950 \mu \mathrm{g} / \mathrm{L}$ in treated water samples. Average concentration values of THMs in primary and secondary disinfection samples exceeded the standard maximum contaminant levels. Results for the average THMs concentrations followed the order TCM > BDCM > DBCM > TBM. EPA-developed models were adopted for the estimation of chronic daily intakes (CDI) and excess cancer incidence through ingestion pathway. Higher average intake was observed in adults $\left(4.52 \times 10^{-2} \mathrm{mg} / \mathrm{kg}\right.$-day), while the ingestion in children $\left(3.99 \times 10^{-2} \mathrm{mg} / \mathrm{kg}\right.$-day $)$ showed comparable values. The total lifetime cancer incidence rate was relatively higher in adults than children with median values 244 and 199 times the negligible risk level.

\section{Introduction}

In sub-Saharan Africa, uncontrolled microbiological contamination of drinking water sources is a commonplace and perennially presents a significant threat to public health. Disinfection is a critical step in drinking water treatment usually performed to safeguard the public health from pathogenic microbes and waterborne diseases [1-7]. Harmful pathogens in water are destroyed by the use of disinfectants such as chlorine, chlorine dioxide, chloramine, ozone, and ultraviolet (UV) light [8-10]. However, some naturally occurring organic matter, anthropogenic contaminants, bromide, and iodide are also present in water, and when a chemical disinfectant such as chlorine is added to water, it tends to react with organic matter to form disinfection byproducts (DBPs), which are known to have adverse health effects on humans [9, 11-14]. Many disinfection byproducts (DBPs) are known for their carcinogenic, mutagenic, cytotoxic, genotoxic, or teratogenic effects $[12,13,15-18]$. However, the formation of DBPs is a function of several factors such as the $\mathrm{pH}$, temperature, source water characteristics, type of disinfectant, and residence time [19-23].
The disinfection of water is an essential treatment process for safeguarding the quality of drinking water but could create undesirable chemical risk due to the formation of disinfection byproducts during chloramination, chlorination, and ozonation with natural organic matter. Since the early seventies, studies have revealed that chlorination produces potentially harmful DBPs with more than 600 DBPs detected and quantified in drinking waters [24]. Identified classes of DBPs include trihalomethanes (THMs), haloacetic acids (HAAs), haloacetaldehydes (HALs), haloketones (HKs), and nitrogenous DBPs (N-DBPs) such as haloacetonitriles (HANs), halonitromethanes (HNMs), and haloacetamides (HAcAms) [3, 25-29]. However, with the advancement in analytical methods and capabilities, emerging DBPs such as halobenzoquinones and iodotrihalomethanes have been identified [30-33]. There are two major classes of DBPs that have been regulated by US Environmental Protection Agency (USEPA) with maximum contaminant level (MCL) of 60 and $80 \mu \mathrm{g} / \mathrm{L}$ for five HAAs and four THMs, respectively $[34,35]$. The trihalomethanes are produced through the interaction of chlorine and chloramine with organic and inorganic matter in water. The THMs include bromodichloromethane (BDCM), 
dibromochloromethane (DBCM), bromoform (TBM), and chloroform (TCM), while the HAAs include dichloroacetic acid, trichloroacetic acid, chloroacetic acid, bromoacetic acid, and dibromoacetic acid $[9,34]$. Other identified DBPs that are not regulated include the halonitromethanes, iodoacids, and other unregulated haloacids, iodotrihalomethanes, and other unregulated halomethanes, halofuranones (MX [3-chloro4-(dichloromethyl)-5-hydroxy-2(5H)-furanone] and brominated MX DBPs), haloamides, haloacetonitriles, haloketones, tribromopyrrole, aldehydes, and N-nitrosodimethylamine (NDMA) and other nitrosamines. Possible health hazards of drinking water that contains the unregulated DBPs is however on the increase with the nonavailability of nonchlorinated or alternative disinfectants. Several epidemiological studies have reported that health complications, associated with liver, reproductive system, kidney, and central nervous system, increased risk of cancer due to consumption of drinking water that contains DBPs in excess of the maximum contaminant level (MCL) [5, 34-37].

According to documented report based on World Health Organization/UNICEF pilot study carried out in twelve states across eight hydrological areas in Nigeria, about $75 \%$ and $50 \%$ of water samples from protected dug wells and utility piped water (including water treatment plants) supplies are potentially contaminated with thermotolerant and faecal streptococci, respectively. Free chlorine was equally detected in piped water systems at levels $\geq 0.2 \mathrm{mg} / \mathrm{l}$, (above maximum permissible level), which was attributed to poor dosing prior to distribution $[38,39]$. In Nigeria, chlorine is widely used as the primary disinfectant because of its availability, relatively low cost, high efficiency, and convenience of application in water purification. Approximately, $99.8 \%$ of public and private drinking water treatment plants (DWTPs) in Nigeria use chlorine for disinfection $[38,40]$. Although there is no recent large-scale water quality survey, which may be due to failure of government policy, negligence by responsible agency, and paucity of information regarding the occurrences of disinfection byproducts, many Nigerians may be exposed to these carcinogens through drinking water. The present study was carried out to determine the occurrence of chlorination byproducts in drinking water from four water treatment plants (WTPs) in Lagos and Ogun States, Nigeria. An attempt was also made to evaluate the potential health risks associated with possible long-term exposure to THMs through ingestion exposure pathway in adults and children.

\section{Materials and Method}

2.1. Sample Collection and Pretreatment. Four potable water treatment plants (WTPs) that utilize one of the two main treatment processes (chlorine-chlorine, chlorine-UV) used in Nigeria were selected for this study. Public and private WTPs in Lagos and Ogun States were selected and these include two public (OW and LW) and two private (HW and SW) water treatment plants. The codes used in the present study were adopted to protect the corporate identities of the companies involved. At the public water works, water is sourced from surface water (river) with the help of $33 \mathrm{~kW}$ low lift pump. Large debris and other particulate matters are prevented from entering the treatment process by coarse screens as the raw water flows into a tank. Coagulation, flocculation, and sedimentation processes are all done in a large rectangular reactor clarifier (RC). Preliming (using aluminium sulphate, $\left.\mathrm{Al}_{2}\left(\mathrm{SO}_{4}\right)_{3}\right)$ and prechlorination (using $30 \mathrm{ppm}$ chlorine powder) are performed simultaneously while the raw water is in the reactor clarifier. Water from the $\mathrm{RC}$ is pumped into several filter beds, which consist of layers of sand and gravels on top of the underdrain nozzles at the bottom of the filter beds. Any particulate matter that escapes the sedimentation process is trapped in the filter beds and thereafter directed through the underdrain nozzles designed to retain the filter media and allow the flow of water. From the filter beds, water is channeled into large reservoirs at the base of the treatment plant. Prior to the filtration process, backwashing is done to remove the debris that might have accumulated in the filter beds. This involves forcing water through the media in an opposite direction to isolate the filter from the treatment process and agitating the surface with the use of compressed air to loosen and flush the debris that has accumulated on it into the waste holding tank. A secondary disinfection involving chlorination is done to maintain a chlorine residual of $0.2 \mathrm{ppm}$ as the water moves from the filter beds into reservoirs prior to distribution through an underground network of pipes for public consumption.

However, at the private water plants, raw groundwater (a borehole) is pumped into an aeration tank. It is subjected to prechlorination and preliming in the treatment tank where it is allowed to stand for six to eight hours to ensure enough contact time. Industrial filter tanks containing activated carbon and resins are employed to remove iron $(\mathrm{Fe})$, odour, taste, and microsized particles from the water. The secondary disinfection is carried out by allowing the treated water to flow from the overhead tanks through the UV disinfection system, prior to packaging. The treatment goal of chlorination is to kill germs, thus inhibiting further biological activities, while improving the taste and odour of water. Raw water samples were taken directly from respective sources prior to primary disinfection process. More so, primary disinfection samples were collected from the large reservoirs after the primary disinfection stage, while the secondary water samples were obtained at the point of the distribution into pipes/packaging. Sampling of raw, primary, and secondary water samples from the public and private WTPs took place between January and May 2015. Water samples were taken in clean and well-marked $40 \mathrm{~mL}$ glass vials with screw caps lined with Teflon-faced septa. Each vial was filled to overflow ensuring that there are no air bubbles and headspace. After collection, $25 \mathrm{mg}$ of ascorbic acid was added to each vial as a reducing agent to quench further production of disinfection byproducts (DBPs). The vials were then sealed and samples stored at $4^{\circ} \mathrm{C}$ prior to analyses.

2.2. Reagents and Solutions. All the reagents and chemicals used in this work are of HPLC grade and of highest purity. nPentane and $\mathrm{n}$-hexane were purchased from Scharlau Chemie SA, Spain. An AccuStandard ${ }^{\circledR}$ Incorporated, USA, Commercial Stock Standard of Trihalomethanes Mix $\left(1000 \mu \mathrm{g} \mathrm{mL}^{-1}\right)$ supplied with certificate of analysis was used for preparing 
TABLE 1: Summary statistics for raw water samples collected from private and public water treatment plants.

\begin{tabular}{lcccccc}
\hline & $\mathrm{pH}$ & Temp. $\left({ }^{\circ} \mathrm{C}\right)$ & Chloride $(\mathrm{mg} / \mathrm{L})$ & TDS $(\mathrm{mg} / \mathrm{L})$ & TOC $(\mathrm{mg} / \mathrm{L})$ & Res. Cl $(\mathrm{mg} / \mathrm{L})$ \\
\hline HWR & $6.78 \pm 0.16$ & $20.31 \pm 0.13$ & $70.09 \pm 0.26$ & $48.50 \pm 8.59$ & $4.93 \pm 0.13$ & 0.00 \\
SWR & $6.91 \pm 0.14$ & $20.79 \pm 0.06$ & $67.76 \pm 2.89$ & $49.70 \pm 8.86$ & $5.12 \pm 0.89$ & 0.00 \\
OWR & $6.90 \pm 0.15$ & $21.88 \pm 0.59$ & $77.92 \pm 1.57$ & $52.32 \pm 5.33$ & $6.52 \pm 1.50$ & 0.00 \\
LWR & $6.98 \pm 0.13$ & $21.72 \pm 0.52$ & $75.88 \pm 1.78$ & $53.94 \pm 5.85$ & $7.34 \pm 1.61$ & 0.00 \\
\hline
\end{tabular}

simple and matrix-matching standard solutions for the calibration of GC-ECD instruments. Using the stock standard, nine calibration standards were prepared. Methanol and ascorbic acid used in the present work were sourced from Tedia Company Incorporated, USA. HPLC grade dichloromethane was purchased from Sigma Aldrich, USA.

2.3. Preparation of Internal Standard. The internal standard was prepared by dissolving $5 \mu \mathrm{L}$ dichloromethane in $10 \mathrm{~mL}$ hexane and well mixed by hand shaking. $50 \mu \mathrm{L}$ of this solution was added to $50 \mathrm{~mL}$ of pentane before the pentane was added to the sample to be extracted.

2.4. Extraction and Instrumental Analysis. Trihalomethanes (THMs) were isolated using a liquid-liquid extraction with HPLC grade pentane, and analyses were carried out using a gas chromatograph (GC) (7890A, Agilent, USA) with autosampler (7683B, Agilent, USA) equipped with an electron capture detector (ECD) based on USEPA method 551.1 [29]. Prior to analysis, the instrument was calibrated after preparing a multicomponent working standard from the stock standard (Stock Standard of Trihalomethanes Mix, $1000 \mu \mathrm{g} \mathrm{mL}^{-1}$, AccuStandard Incorporated, USA) by making appropriate dilutions of the stock solution with methanol in a volumetric flask. The concentrations in ppm were chosen such that the calibration standards used between 2 and $20 \mu \mathrm{L}$ of working standard per $1000 \mu \mathrm{L}$ of methanol. In order to prepare the samples for analysis, the screw top vial was opened and $5 \mathrm{~mL}$ of the solution was removed. The vial was recapped and weighed to the nearest $\pm 0.1 \mathrm{mg}$. Subsequently, $2.0 \mathrm{~mL}$ of pentane (with the internal standard) was added to each vial and shaken vigorously for one minute $(1 \mathrm{~min})$. The two phases were allowed to separate for two minutes ( $2 \mathrm{~min}$ ) and a glass pipette was then used to transfer at $1 \mathrm{~mL}$ of the pentane (the upper phase) to a $1.8 \mathrm{~mL}$ screw top sample vial with a TFE septum and thereafter stored at $4^{\circ} \mathrm{C}$ until the sample was loaded into the autosampler for injection into the GC. The instrument was programmed to inject a $1 \mu \mathrm{L}$ aliquot of the pentane extracts into a GC equipped with a $30 \mathrm{~m}$ fused silica column with an internal diameter of $0.32 \mathrm{~mm}$ and a $1 \mu \mathrm{m}$ coating of the stationary phase DB-1 (J\&W Scientific, USA). A linear flow rate of $20 \mathrm{~cm} / \mathrm{s}$ is used with the following temperature program: hold for $5 \mathrm{~min}$ at $35^{\circ} \mathrm{C}$, increase to $70^{\circ} \mathrm{C}$ at $10^{\circ} \mathrm{C} / \mathrm{min}$, and increase to $200^{\circ} \mathrm{C}$ at $20^{\circ} \mathrm{C}$. Triplicate analyses were performed within 24 hours after extraction for all the samples. The calculated limit of detection (LOD) for dichlorobromomethane, dibromochloromethane, bromoform, and chloroform was $\geq 0.02 \mu \mathrm{g} / \mathrm{L}$. The recoveries of the GC-ECD method for the trihalomethanes were satisfactory and indicated analytical precisions of 99.43, 99.36, 99.48, and 99.53\% for chloroform, dichlorobromomethane, dibromochloromethane, and bromoform, respectively. This ascertained the reproducibility of this method.

\section{Results and Discussion}

3.1. Characteristics of Raw Water Samples. The $\mathrm{pH}$, temperature, chloride, total organic carbon (TOC), total dissolved solids (TDS), and residual chlorine measured for raw water samples from the private and public water treatment plants are presented in Table 1.

The raw water samples had $\mathrm{pH}$ values that were within the neutral $\mathrm{pH}$ range of 6.5 and 7.5 , and the temperature ranged between $20.31 \pm 0.13$ and $21.88 \pm 0.59^{\circ} \mathrm{C}$. The chloride concentrations in the raw water samples were relatively higher in both the private and public water treatment plants. It ranged from $67.76 \pm 2.89 \mathrm{mg} / \mathrm{L}$ in SW (private WTP) samples to $77.92 \pm 1.57 \mathrm{mg} / \mathrm{L}$ in the public sourced raw water samples (Table 1). Chloride occurrence in enhanced concentration is regarded as a pollutant and may be introduced into surface and groundwater from anthropogenic and natural sources including industrial effluents, septic tank effluents, leachates from landfill, inorganic fertilisers from agricultural use, and saltwater intrusion into coastal inshore waters [41, 42]. The total organic carbon is essentially required as a precursor for the formation of DBPs. The TOC levels in raw water samples were not so high, ranging from $4.93 \pm 0.13$ to $7.34 \pm 1.61 \mathrm{mg} / \mathrm{L}$. The TDS levels, however, ranged from $48.50 \pm 8.59$ to $53.94 \pm$ $5.85 \mathrm{mg} / \mathrm{L}$. As expected, the TDS levels in raw water samples obtained from the open surface water were relatively higher than those sourced from underground water.

3.2. Concentrations of Trihalomethanes. The concentrations of the trihalomethanes (Table 2) in investigated water samples are presented in this section. Generally, the mean concentrations of the trihalomethanes as determined for the water samples were found to vary at different treatment stages (raw, primary, and secondary disinfection stages). The THMs were not detected in the raw water because disinfection had not been undertaken at that stage of the drinking water treatment. However, the detection of halogenated disinfection byproducts in primary and secondary water samples is likely due to the interaction of natural organic matter in raw water with chlorine disinfectant $[43,44]$.

The average concentrations of trihalomethanes in primary and secondary water samples from the WTPs generally followed the sequence TCM $>\mathrm{BDCM}>\mathrm{TBM}=\mathrm{DBCM}$, which was consistent with similar documented reports [3, $5,45,46]$. The total concentrations of the THMs (TCM + $\mathrm{BDCM}+\mathrm{TBM}+\mathrm{DBCM}$ ) in primary water samples ranged 
TABLE 2: Average concentration $(\mu \mathrm{g} / \mathrm{L})(n=3)$ of trihalomethanes in raw, primary, and secondary water samples from WTPs obtained between January and May 2015.

\begin{tabular}{|c|c|c|c|c|c|}
\hline Source & TCM & BDCM & DBCM & TBM & TTHMs \\
\hline \multicolumn{6}{|c|}{ Jan. } \\
\hline OWR & $\mathrm{BD}$ & $\mathrm{BD}$ & $\mathrm{BD}$ & $\mathrm{BD}$ & 0 \\
\hline OWP & 997.43 & $\mathrm{BD}$ & $\mathrm{BD}$ & 0.40 & 997.83 \\
\hline OWS & 960.68 & $\mathrm{BD}$ & $\mathrm{BD}$ & $\mathrm{BD}$ & 960.68 \\
\hline LWR & $\mathrm{BD}$ & $\mathrm{BD}$ & $\mathrm{BD}$ & $\mathrm{BD}$ & 0 \\
\hline LWP & 716.04 & 0.42 & 0.38 & $\mathrm{BD}$ & 716.84 \\
\hline LWS & 825.04 & $\mathrm{BD}$ & $\mathrm{BD}$ & $\mathrm{BD}$ & 825.04 \\
\hline HWR & $\mathrm{BD}$ & $\mathrm{BD}$ & $\mathrm{BD}$ & $\mathrm{BD}$ & 0 \\
\hline HWP & 755.70 & $\mathrm{BD}$ & $\mathrm{BD}$ & $\mathrm{BD}$ & 755.70 \\
\hline HWS & 812.35 & $\mathrm{BD}$ & $\mathrm{BD}$ & $\mathrm{BD}$ & 812.35 \\
\hline SWR & $\mathrm{BD}$ & $\mathrm{BD}$ & $\mathrm{BD}$ & $\mathrm{BD}$ & 0 \\
\hline SWP & 999.64 & $\mathrm{BD}$ & $\mathrm{BD}$ & $\mathrm{BD}$ & 999.64 \\
\hline SWS & 950.97 & $\mathrm{BD}$ & $\mathrm{BD}$ & $\mathrm{BD}$ & 950.97 \\
\hline \multicolumn{6}{|c|}{ Feb. } \\
\hline OWR & $\mathrm{BD}$ & $\mathrm{BD}$ & $\mathrm{BD}$ & $\mathrm{BD}$ & 0 \\
\hline OWP & 953.77 & $\mathrm{BD}$ & $\mathrm{BD}$ & $\mathrm{BD}$ & 953.77 \\
\hline OWs & 887.34 & $\mathrm{BD}$ & $\mathrm{BD}$ & $\mathrm{BD}$ & 887.34 \\
\hline LWR & $\mathrm{BD}$ & $\mathrm{BD}$ & $\mathrm{BD}$ & $\mathrm{BD}$ & 0 \\
\hline LWP & 900.70 & 0.42 & $\mathrm{BD}$ & $\mathrm{BD}$ & 901.12 \\
\hline LWS & 825.04 & $\mathrm{BD}$ & $\mathrm{BD}$ & $\mathrm{BD}$ & 825.04 \\
\hline HWR & $\mathrm{BD}$ & $\mathrm{BD}$ & $\mathrm{BD}$ & $\mathrm{BD}$ & 0 \\
\hline HWP & 916.94 & $\mathrm{BD}$ & $\mathrm{BD}$ & $\mathrm{BD}$ & 916.94 \\
\hline HWS & 872.00 & $\mathrm{BD}$ & $\mathrm{BD}$ & $\mathrm{BD}$ & 872.00 \\
\hline SWR & $\mathrm{BD}$ & $\mathrm{BD}$ & $\mathrm{BD}$ & $\mathrm{BD}$ & 0 \\
\hline SWP & 906.38 & $\mathrm{BD}$ & $\mathrm{BD}$ & $\mathrm{BD}$ & 906.38 \\
\hline SWS & 712.50 & $\mathrm{BD}$ & $\mathrm{BD}$ & $\mathrm{BD}$ & 712.50 \\
\hline \multicolumn{6}{|c|}{ Mar. } \\
\hline OWR & $\mathrm{BD}$ & $\mathrm{BD}$ & $\mathrm{BD}$ & $\mathrm{BD}$ & 0 \\
\hline OWP & 561.86 & $\mathrm{BD}$ & $\mathrm{BD}$ & $\mathrm{BD}$ & 561.86 \\
\hline OWs & 582.32 & 0.41 & $\mathrm{BD}$ & $\mathrm{BD}$ & 582.73 \\
\hline LWR & $\mathrm{BD}$ & $\mathrm{BD}$ & $\mathrm{BD}$ & $\mathrm{BD}$ & 0 \\
\hline LWP & 620.55 & $\mathrm{BD}$ & $\mathrm{BD}$ & $\mathrm{BD}$ & 620.55 \\
\hline LWS & 846.79 & 0.41 & $\mathrm{BD}$ & $\mathrm{BD}$ & 847.20 \\
\hline HWR & $\mathrm{BD}$ & $\mathrm{BD}$ & $\mathrm{BD}$ & $\mathrm{BD}$ & 0 \\
\hline HWP & 777.70 & $\mathrm{BD}$ & $\mathrm{BD}$ & $\mathrm{BD}$ & 777.70 \\
\hline HWS & 803.42 & $\mathrm{BD}$ & $\mathrm{BD}$ & $\mathrm{BD}$ & 803.42 \\
\hline SWR & $\mathrm{BD}$ & $\mathrm{BD}$ & $\mathrm{BD}$ & $\mathrm{BD}$ & 0 \\
\hline SWP & 624.54 & $\mathrm{BD}$ & $\mathrm{BD}$ & $\mathrm{BD}$ & 624.54 \\
\hline SWS & 591.99 & $\mathrm{BD}$ & $\mathrm{BD}$ & $\mathrm{BD}$ & 591.99 \\
\hline \multicolumn{6}{|c|}{ Apr. } \\
\hline OWR & $\mathrm{BD}$ & $\mathrm{BD}$ & $\mathrm{BD}$ & $\mathrm{BD}$ & 0 \\
\hline OWP & 31.21 & $\mathrm{BD}$ & $\mathrm{BD}$ & $\mathrm{BD}$ & 31.21 \\
\hline OWs & 28.34 & 0.41 & $\mathrm{BD}$ & $\mathrm{BD}$ & 28.75 \\
\hline LWR & $\mathrm{BD}$ & $\mathrm{BD}$ & $\mathrm{BD}$ & $\mathrm{BD}$ & 0 \\
\hline LWP & 21.92 & $\mathrm{BD}$ & $\mathrm{BD}$ & $\mathrm{BD}$ & 21.92 \\
\hline LWS & 28.44 & $\mathrm{BD}$ & $\mathrm{BD}$ & $\mathrm{BD}$ & 28.44 \\
\hline HWR & $\mathrm{BD}$ & $\mathrm{BD}$ & $\mathrm{BD}$ & $\mathrm{BD}$ & 0 \\
\hline HWP & 28.25 & $\mathrm{BD}$ & $\mathrm{BD}$ & $\mathrm{BD}$ & 28.25 \\
\hline HWS & 30.03 & $\mathrm{BD}$ & $\mathrm{BD}$ & $\mathrm{BD}$ & 30.03 \\
\hline SWR & $\mathrm{BD}$ & $\mathrm{BD}$ & $\mathrm{BD}$ & $\mathrm{BD}$ & 0 \\
\hline SWP & 28.87 & $\mathrm{BD}$ & $\mathrm{BD}$ & $\mathrm{BD}$ & 28.87 \\
\hline SWS & 32.11 & $\mathrm{BD}$ & $\mathrm{BD}$ & $\mathrm{BD}$ & 32.11 \\
\hline
\end{tabular}


TABLe 2: Continued.

\begin{tabular}{|c|c|c|c|c|c|}
\hline Source & TCM & BDCM & DBCM & TBM & TTHMs \\
\hline \multicolumn{6}{|c|}{ May } \\
\hline OWR & $\mathrm{BD}$ & $\mathrm{BD}$ & $\mathrm{BD}$ & $\mathrm{BD}$ & 0 \\
\hline OWP & 30.45 & $\mathrm{BD}$ & $\mathrm{BD}$ & $\mathrm{BD}$ & 30.45 \\
\hline OWS & 34.15 & $\mathrm{BD}$ & $\mathrm{BD}$ & $\mathrm{BD}$ & 34.15 \\
\hline LWR & $\mathrm{BD}$ & $\mathrm{BD}$ & $\mathrm{BD}$ & $\mathrm{BD}$ & 0 \\
\hline LWP & 27.20 & $\mathrm{BD}$ & $\mathrm{BD}$ & $\mathrm{BD}$ & 27.20 \\
\hline LWS & 26.89 & $\mathrm{BD}$ & $\mathrm{BD}$ & $\mathrm{BD}$ & 26.89 \\
\hline HWR & $\mathrm{BD}$ & $\mathrm{BD}$ & $\mathrm{BD}$ & $\mathrm{BD}$ & 0 \\
\hline HWP & 32.90 & $\mathrm{BD}$ & $\mathrm{BD}$ & $\mathrm{BD}$ & 32.90 \\
\hline HWS & 29.20 & $\mathrm{BD}$ & $\mathrm{BD}$ & $\mathrm{BD}$ & 29.20 \\
\hline SWR & $\mathrm{BD}$ & $\mathrm{BD}$ & $\mathrm{BD}$ & $\mathrm{BD}$ & 0 \\
\hline SWP & 32.50 & $\mathrm{BD}$ & $\mathrm{BD}$ & $\mathrm{BD}$ & 32.50 \\
\hline SWS & 32.10 & $\mathrm{BD}$ & $\mathrm{BD}$ & $\mathrm{BD}$ & 32.10 \\
\hline
\end{tabular}

R: raw, P: primary, S: secondary disinfection samples, and BD: below detection limit.

from 21.92 to $997.43 \mu \mathrm{g} / \mathrm{L}$ and 28.25 to $999.64 \mu \mathrm{g} / \mathrm{L}$ in public and private water treatment plants, respectively. On the other hand, the TTHMs determined in water samples obtained from the secondary disinfection process ranged from 26.89 to $960.68 \mu \mathrm{g} / \mathrm{L}$ in public WTPs and 29.20 to $950.97 \mu \mathrm{g} / \mathrm{L}$ in private WTPs. This study shows that the total concentration of THMs found in the public and private water treatment plants during the first three months of study was relatively higher compared with published studies carried out in some countries [5, 47-50]. In general, the total concentrations of the DBPs of all primary and secondary disinfection water samples collected between January and May were above the guideline value of $0.001 \mathrm{mg} / \mathrm{L}$ stipulated by Standard Organization of Nigeria as "Nigerian Standard for Drinking Water Quality" (ICS 13.060.20) [39]. Generally speaking, there was a remarkable drop in total trihalomethanes levels in public and private water supplies between January and April, which continued into May during the sampling period. This reduction may have been attributed to the advice given to the managers of the WTPs regarding the very high concentrations of TTHMs recorded after three-months analysis, and the attempt to ensure that the levels of THMs are reduced to acceptable limit. In the present study, it was observed that TTHMs in the several treatment and distribution stages of the WTPs indicated enhanced concentrations during storage in the treatment tanks. This may be attributed to increase in TOC caused by the development of biofilms as a result of fluctuations in the water levels in the tanks.

In surface and groundwater sources, the organic matter is predominantly derived from decayed or living plant materials. This natural organic matter is present in water sources in dissolved, particulate, and colloidal forms [51]. The increased total organic carbon provides more dissolved organic matter as DBP precursor to generate more of the THMs during storage in the final treatment tanks. This is in agreement with previous reports by $[50,52]$.

3.3. Exposure Assessment. Risk assessment is a vital tool for regulation and prioritization of chemical contaminants in drinking water and could be expressed in terms of specific disease endpoints (e.g., cancer) [5, 49, 53]. However, based on the DBP distributions, an exposure assessment could be conducted to evaluate the potential intake of DBPs through multiple pathways such as inhalation and dermal and ingestion exposures. For this study, ingestion and dermal exposures were considered to be the major activity for possible contacts with THMs. In Nigeria, there is no availability of data on the shower habits of inhabitants of the investigated areas. Therefore, the estimates for shower frequency $(F)$ and shower duration $(t)$ were not available for computation of inhalation and dermal exposures. The chronic daily intake (CDI) estimate for the ingestion pathway was calculated by the following equation:

$$
\mathrm{CDI}_{\text {ing }}=\frac{C_{w} \times \mathrm{IR}_{w} \times \mathrm{EF} \times \mathrm{ED} \times \mathrm{CF}}{\mathrm{BW}_{a} \times \mathrm{AT}},
$$

where $\mathrm{CDI}_{\text {ing }}$ is the value for chronic daily intake via ingestion pathway (mg/kg/day), $C_{w}$ is the concentration of THMs in drinking water $(\mu \mathrm{g} / \mathrm{L}), \mathrm{IR}_{w}$ is the water ingestion rate (L/day), $\mathrm{EF}$ is the exposure frequency (days/year), ED is the total exposure duration (years), AT is the averaging time (i.e., exposure duration $\times 365$ days), and $\mathrm{BW}_{a}$ is the average body weight $(\mathrm{kg}) ; \mathrm{CF}=$ mass conversion factor from $\mu \mathrm{g}$ to $\mathrm{mg}(0.001)$. The reference dose, which is defined as the maximum level of the safe dose, for chloroform (TCM), bromodichloromethane (BDCM), dibromochloromethane (DBCM), and bromoform (TBM), is reported to be 0.01 , $0.02,0.02$, and $0.02 \mathrm{mg} / \mathrm{kg}$-day, respectively [54]. The average body weight for adults and children (age range 6-18 years), in Nigeria, was $70 \mathrm{~kg}$ and $48 \mathrm{~kg}$, respectively. $\mathrm{IR}_{w}$ for adults and children were estimated at $3.3 \mathrm{~L} /$ day and $2.0 \mathrm{~L} /$ day, respectively. The exposure frequency (EF) used in the present study is estimated at 350 days/year. The ED is 52.5 years (World Bank 2013 estimate for average life expectancy of an adult in Nigeria) [55].

The chronic daily intake of THMs through ingestion route of exposure is presented in Tables 3(a) and 3(b). The 


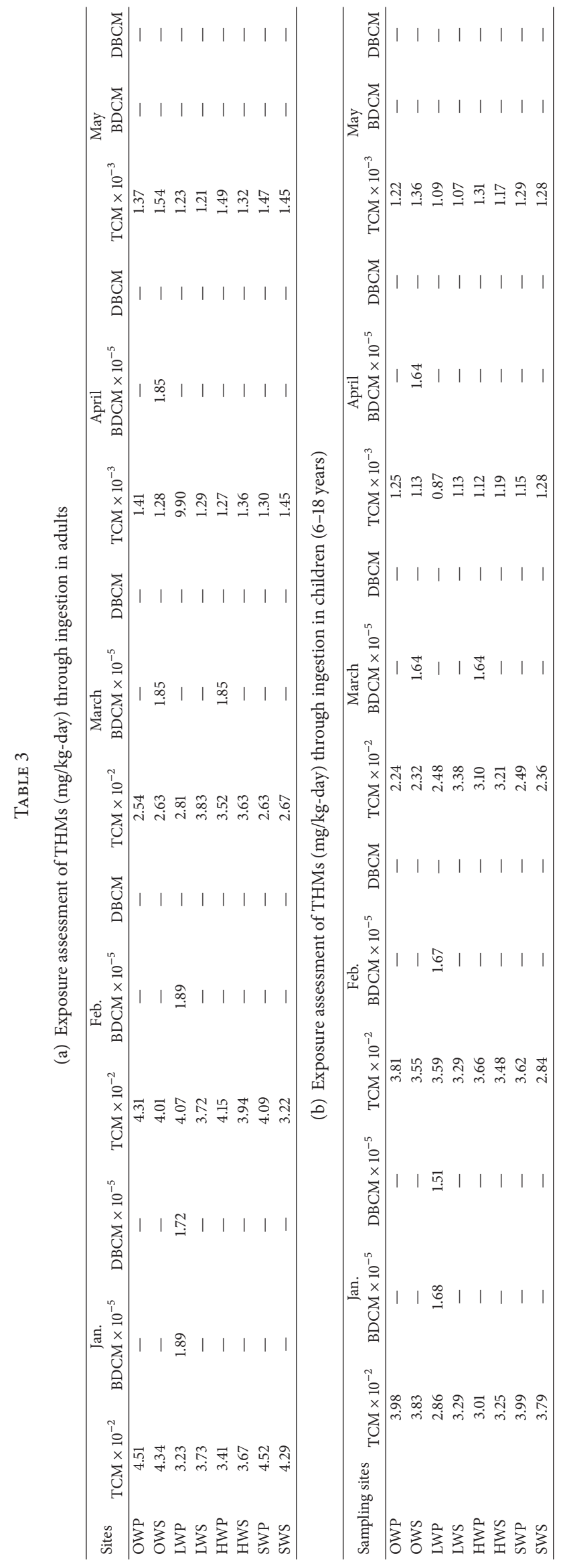


TABLE 4

(a) Lifetime incidence rates of developing cancer by exposure to chloroform in adults

\begin{tabular}{lcccrr}
\hline Sampling sites & Jan. & Feb. & Mar. & Apr. \\
\hline OWP & $2.7504 E-04$ & $2.6301 E-04$ & $1.6043 E-06$ & $8.6062 E-06$ & $8.3966 E-06$ \\
OWS & $2.6491 E-04$ & $2.4468 E-04$ & $1.4925 E-06$ & $7.8148 E-06$ & $9.4169 E-06$ \\
LWP & $1.9745 E-04$ & $2.4837 E-04$ & $1.5150 E-06$ & $6.0445 E-06$ & $7.5004 E-06$ \\
LWS & $2.2750 E-04$ & $2.2750 E-04$ & $1.3878 E-06$ & $7.8424 E-06$ & $7.4150 E-06$ \\
HWP & $2.0838 E-04$ & $2.5285 E-04$ & $1.5423 E-06$ & $7.7900 E-06$ & $9.0722 E-06$ \\
HWS & $2.2401 E-04$ & $2.4045 E-04$ & $1.4667 E-06$ & $8.2808 E-06$ & $8.0520 E-06$ \\
SWP & $2.7565 E-04$ & $2.4993 E-04$ & $1.5246 E-06$ & $7.9610 E-06$ & $8.9619 E-06$ \\
SWS & $2.6223 E-04$ & $1.9647 E-04$ & $1.1984 E-06$ & $8.8544 E-06$ & $8.8516 E-06$ \\
\hline
\end{tabular}

(b) Lifetime incidence rates of developing cancer by exposure to chloroform in children

\begin{tabular}{lcccrr}
\hline Sampling sites & Jan. & Feb. & Mar. & Apr. & May \\
\hline OWP & $2.4309 E-04$ & $2.3245 E-04$ & $1.3693 E-04$ & $7.6065 E-06$ & $7.4213 E-06$ \\
OWS & $2.3414 E-04$ & $2.1626 E-04$ & $1.4192 E-04$ & $6.9070 E-06$ & $8.3230 E-06$ \\
LWP & $1.7451 E-04$ & $2.1952 E-04$ & $1.5124 E-04$ & $5.3424 E-06$ & $6.6292 E-06$ \\
LWS & $2.0108 E-04$ & $2.0108 E-04$ & $2.0638 E-04$ & $6.9314 E-06$ & $6.5536 E-06$ \\
HWP & $1.8418 E-04$ & $2.2347 E-04$ & $1.8954 E-04$ & $6.8851 E-06$ & $8.0184 E-06$ \\
HWS & $1.9798 E-04$ & $2.1252 E-04$ & $1.9581 E-04$ & $7.3189 E-06$ & $7.1166 E-06$ \\
SWP & $2.4363 E-04$ & $2.2090 E-04$ & $1.5221 E-04$ & $7.0362 E-06$ & $7.9209 E-06$ \\
SWS & $2.3177 E-04$ & $1.7365 E-04$ & $1.4428 E-04$ & $7.8259 E-06$ & $7.8234 E-06$ \\
\hline
\end{tabular}

TABLE 5: Total cancer incidence rate $\left(\times 10^{-4}\right)$ by exposure to chloroform in adults and children.

\begin{tabular}{lcccccccrrr}
\hline & \multicolumn{2}{c}{ Jan. } & \multicolumn{2}{c}{ Feb. } & \multicolumn{2}{c}{ Mar. } & \multicolumn{2}{c}{ Apr. } & \multicolumn{2}{c}{ May } \\
& ADT & CHD & ADT & CHD & ADT & CHD & ADT & CHD & ADT & CHD \\
\hline OW & 5.3996 & 4.7723 & 5.0769 & 4.4872 & 3.1551 & 2.7886 & 0.1642 & 0.1451 & 0.1781 & 0.1574 \\
LW & 4.2496 & 3.7559 & 4.7588 & 4.2060 & 4.0662 & 3.5762 & 0.1386 & 0.1227 & 0.1491 & 0.1318 \\
HW & 4.3240 & 3.8217 & 4.9331 & 4.3600 & 4.3600 & 3.8535 & 0.1607 & 0.1420 & 0.1420 & 0.1513 \\
SW & 5.3789 & 4.7541 & 4.4641 & 3.9456 & 3.3546 & 2.9649 & 0.1682 & 0.1486 & 0.1486 & 0.1574 \\
\hline
\end{tabular}

highest intakes were observed in adults, while the ingestion in children aged between 6 and 18 years showed comparable values. In all water distribution systems investigated, the intakes of chloroform were highest with $4.52 \times 10^{-2}$ and $3.99 \times 10^{-2} \mathrm{mg} / \mathrm{kg}$-day in adults and children, respectively. These high intakes may pose higher risks to human health in Nigeria.

3.4. Evaluation of Lifetime Cancer Incidence Rates. The lifetime incidence rates (LIR) of developing cancer from exposure to different DBPs through different pathways were calculated using (2). In addition, the total cancer incidence rate (TIR) was calculated using an additive model as shown in (3):

$$
\begin{aligned}
\mathrm{LIR}_{i, j} & =\mathrm{CDI}_{i, j} \times \mathrm{SF}_{i, j}, \\
\mathrm{TIR} & =\sum_{i, j} \mathrm{CDI}_{i, j} \times \mathrm{SF}_{i, j},
\end{aligned}
$$

where $i$ is exposure pathway, $j$ is THM, and SF is slope factor. The slope factors adopted for this study were $6.10 \times$ $10^{-3}$ (TCM), $6.20 \times 10^{-2}(\mathrm{BDCM}), 8.40 \times 10^{-2}(\mathrm{DBCM})$, and $7.90 \times 10^{-2}(\mathrm{TBM})$. Slope factors are estimated from animal toxicity data by various models, approximating $95 \%$ confidence limits. So, the calculated cancer incidence can be interpreted as the upper bound lifetime probability of an individual's developing cancer. The LIRs of developing cancer by exposure to chloroform in adults and children in Nigeria are presented in Tables 4(a) and 4(b), respectively. However, the total lifetime cancer incidence rates are presented in Table 5. Overall, the EPA mode of action (MOA) approach (a nonlinear approach) for the risk assessment on TCM set at a threshold of $0.01 \mathrm{mg} / \mathrm{kg} /$ day was not exceeded.

The median values and 5th and 95th percentiles of the cancer risk distributions from exposure to chloroform through ingestion pathway are summarized in Table 6. Results indicated that the median values of the total lifetime incidence in adults due to exposure to TCM ranged between $1.67 \times 10^{-4}$ and $2.24 \times 10^{-4}$ in OW and HW water disinfection systems, respectively. Also, the median values of cancer incidences in children, which could be associated to exposure to TCM, varied between $1.47 \times 10^{-4}$ and $1.99 \times 10^{-4}$ in $\mathrm{OW}$ and $\mathrm{HW}$ water systems. It was observed that the total lifetime incidence of developing cancer was relatively higher 
TABLE 6: Excess cancer incidences from exposure to TCM through different ingestion $\left(\times 10^{-4}\right)$ in adults and children.

\begin{tabular}{lcccc}
\hline & OW & LW & HW & SW \\
\hline \multirow{2}{*}{ Adults } & 1.67 & 2.11 & 2.24 & 1.76 \\
& $(0.17,5.32)$ & $(0.14,4.63)$ & $(0.15,4.79)$ & $(0.15,5.15)$ \\
\multirow{2}{*}{ Children } & 1.47 & 1.85 & 1.99 & 1.56 \\
& $(0.15,4.700)$ & $(0.13,4.09)$ & $(0.14,4.23)$ & $(0.15,4.55)$ \\
\hline
\end{tabular}

Data shown are median values of the risk distributions, and values in the parentheses are the 5th and 95th percentiles of the risk distributions.

in adults than children. However, the highest median values in adults and children were 244 and 199 times the minimum or negligible risk level set by the USEPA $\left(1.0 \times 10^{-6}\right)$, but within the regulatory limit defined by USEPA $\left(10^{-6}\right.$ to $10^{-4}$ ). Generally speaking, the presence of regulated DBPs in drinking water highlights the problems associated with chlorination treatment process, which can potentially increase the human exposure to these cancer-causing contaminants. Again, these results support the premise that carcinogenic organic compounds and toxic metals in drinking water and groundwater sources in the country are largely found at concentrations above threshold limits $[38,40,56]$.

\section{Conclusion and Recommendations}

In this study, the concentration of trihalomethanes was assessed in drinking water from four different water treatment plants (HW, OW, LW, and SW) in two heavily populated states in Nigeria. The levels of the total trihalomethanes were found to be higher at the initial stage of the research but gradually reduced probably due to more careful handling of the water treatment processes as the quality control officers were briefed on the results of previous analysis when the next samples were being collected. This is an indication that the treatment processes handling contributes a great deal to the formation of disinfection by-products in drinking water. This has to do partly with carefulness in the addition of chlorine, which is mostly used in all the water treatment plants in the sampled areas; the documented dosage is $20-30 \mathrm{mg} / \mathrm{L}$ but it does not seem this is strictly adhered to. In addition to this are the processes of sedimentation/flocculation and the maintenance of the right amount of residual chlorine in the distribution system.

For the water treatment plants to achieve the SON $(0.001 \mathrm{mg} / \mathrm{L})$ and USEPA $(0.08 \mathrm{mg} / \mathrm{L})$ recommended maximum permissible levels (MCL) for the TTHMs, a constant effort is required to reduce the concentrations of all the DBPs to the barest minimum. This can be achieved by protecting the source water from excessive pollution thereby reducing the DBP precursors. The use of chloramine as disinfectant has proven to produce very minimal amount of DBPs in countries like Europe, America, and Australia. Therefore, a switch from chlorine usage during primary disinfection by DWTPs in Nigeria to chloramine is strongly recommended with ultraviolet light as the secondary disinfectant. Operators of public and private water treatment plants should adopt viable alternative primary disinfection strategies such as using $\mathrm{ClO}_{2}$, ozone, and UV disinfection to chlorination. In addition, a thorough evaluation of the efficiency of WTPs and operational practices of the water treatment processes and the piped distribution network is proposed to examine the possible reasons for the exceedances of TTHMs.

\section{Disclosure}

This research did not receive any specific grant from funding agencies in the public, commercial, or not-for-profit sectors.

\section{Conflicts of Interest}

The authors declare no conflicts of interest.

\section{References}

[1] S. Chowdhury, "Exposure assessment for trihalomethanes in municipal drinking water and risk reduction strategy," Science of the Total Environment, vol. 463-464, pp. 922-930, 2013.

[2] P. Ioannou, P. Charisiadis, S. S. Andra, and K. C. Makris, "Occurrence and variability of iodinated trihalomethanes concentrations within two drinking-water distribution networks," Science of The Total Environment. Part A, pp. 505-513, 2016.

[3] W. B. Y. Jianrong, W. Wuyi, Y. Linsheng, T. Jing, and H. Zhijiu, "Spatial and temporal evaluations of disnfection by-products in drinking water distribution system in Beijing, China," Science of the Total Environment, vol. 408, pp. 4600-4606, 2010.

[4] T. Karanfil, S. W. Krasner, P. Westerhoff, and Y. F. Xie, "Disinfection by-products in drinking water: Information, occurrence, health effects and control," American Chemical Society, vol. Washington, DC, USA, pp. 2-19, 2008.

[5] S. Pan, W. An, H. Li, M. Su, J. Zhang, and M. Yang, "Cancer risk assessment on trihalomethanes and haloacetic acids in drinking water of China using disability-adjusted life years," Journal of Hazardous Materials, vol. 280, pp. 288-294, 2014.

[6] E. Righi, P. Bechtold, D. Tortorici et al., "Trihalomethanes, chlorite, chlorate in drinking water and risk of congenital anomalies: a population-based case-control study in Northern Italy," Environmental Research, vol. 116, pp. 66-73, 2012.

[7] D. Stalter, E. O’Malley, U. von Gunten, and B. I. Escher, "Fingerprinting the reactive toxicity pathways of 50 drinking water disinfection by-products," Water Research, vol. 91, 2016.

[8] W. A. Mitch, A. C. Gerecke, and D. L. Sedlak, "A Nitrosodimethylamine (NDMA) precursor analysis for chlorination of water and wastewater," Water Research, vol. 37, no. 15, pp. 3733-3741, 2003.

[9] S. D. Richardson, "Disinfection by-products: formation and occurrence in drinking water," in Encyclopedia of Environmental Health, J. O. Nriagu and Elsevier., Eds., pp. 110-136, Elsevier, Burlington, Canada, 2011.

[10] X. Zhang, S. Echigo, R. A. Minear, and M. J. Plewa, "Characterization and comparison of disinfection by-products of four major disinfectants," in Natural Organic Matter and Disinfection By-Products: Characterization and Control in Drinking, S. E. Barrett, S. W. Krasner, and G. L. Amy, Eds., pp. 299-314, American Chemical Society, Washington, DC, USA, 2000.

[11] M. M. Anandharihara, S. Satheesh, and B. K. Phillips, "Chlorination by-products," in Encyclopedia of Toxicology, vol. 1, pp. 546-553, Elsevier Inc, 2005. 
[12] Y. Komaki, B. J. Mariñas, and M. J. Plewa, "Toxicity of drinking water disinfection byproducts: Cell cycle alterations induced by the monohaloacetonitriles," Environmental Science and Technology, vol. 48, no. 19, pp. 11662-11669, 2014.

[13] M. J. Plewa, J. E. Simmons, S. D. Richardson, and E. D. Wagner, "Mammalian cell cytotoxicity and genotoxicity of the haloacetic acids, a major class of drinking water disinfection by-products," Environmental and Molecular Mutagenesis, vol. 51, no. 8-9, pp. 871-878, 2010.

[14] M. B. Rahman, T. Driscoll, C. Cowie, and B. K. Armtrong, "Disinfection by-products in drinking water and colorectal cancer: a meta-analysis," International Journal of Epidemiology, vol. 39, no. 3, pp. 733-745.

[15] R. Sayess, A. Khalil, M. Shah, D. A. Reckhow, and K. J. Godri Pollitt, "Comparative cytotoxicity of six iodinated disinfection byproducts on nontransformed epithelial human colon cells," Environmental Science \& Technology Letters, vol. 4, no. 4, pp. 143-148, 2017.

[16] S. D. Richardson, M. J. Plewa, E. D. Wagner, R. Schweny, and D. M. Demarini, "Occurrence, genotoxicity and carcinogenicity of regulated and emerging disinfection by-products in drinking water: a review and roadmap for research," Mutation Research/ Reviews in Mutation Research, vol. 636, pp. 178-242, 2007.

[17] M. J. Plewa, M. G. Muellner, S. D. Richardson et al., "Occurrence, synthesis, and mammalian cell cytotoxicity and genotoxicity of haloacetamides: An emerging class of nitrogenous drinking water disinfection byproducts," Environmental Science \& Technology, vol. 42, no. 3, pp. 955-961, 2008.

[18] S. R. Bielmeier, A. S. Murr, D. S. Best et al., "Effects of bromodichloromethane on ex vivo and in vitro luteal function and bromodichloromethane tissue dosimetry in the pregnant F344 rat," Toxicology in Vitro, vol. 21, no. 5, pp. 919-928, 2007.

[19] S. W. Krasner, "The formation and control of emerging disinfection by-products of health concern," Philosophical Transactions of the Royal Society A: Mathematical, Physical and Engineering Sciences, vol. 367, no. 1904, pp. 4077-4095, 2009.

[20] S. W. Krasner, M. S. Dale, C. F. T. Lee, E. A. Garcia, W. Mitch, and U. Von Gunten, "Effect of water quality and operational parameters on DBP formation during chloramination: NDMA versus halogenated DBPs," in Proceedings of the Annual Conference, American Water Works Association, p. 46, 2010.

[21] L. Liang and P. C. Singer, "Factors influencing the formation and relative distribution of haloacetic acids and trihalomethanes in drinking water," Environmental Science \& Technology, vol. 37, no. 13, pp. 2920-2928, 2003.

[22] E. M. R. Souaya, A. M. Abdullah, and M. Mossad, "Factors affecting on formation of DBPs in greater Cairo drinking water," Organic Chemistry: Current Research, vol. 4, no. 5, p. 2, 2015.

[23] B. Ye, W. Wang, L. Yang, and J. Wei, "Formation and modeling of disinfection by-products in drinking water of six cities in China," Journal of Environmental Monitoring, vol. 13, no. 5, pp. 1271-1275, 2011.

[24] S. E. Hrudey and J. W. A. Charrois, Disinfection By-products and Human Health, IWA Publishing, London, UK, 2012.

[25] T. Bond, J. Huang, M. R. Templeton, and N. Graham, "Occurrence and control of nitrogenous disinfection by-products in drinking water - a review," Water Research, vol. 45, pp. 43414354, 2011.

[26] J. Grellier, L. Rushton, D. J. Briggs, and M. J. Nieuwenhuijsen, "Assessing the human health impacts of exposure to disinfection by-products - A critical review of concepts and methods," Environment International, vol. 78, pp. 61-81.
[27] B. Jurado, E. Ballesteros, and M. Gallego, "Occurrence of carboxylic acids in different steps of two drinking-water treatment plants using different disinfectants," Water Research, vol. 51, pp. 186-197, 2014.

[28] A. D. Nikolaou, S. K. Golfinopoulos, T. D. Lekkas, and M. N. Kostopoulou, "DBP levels in chlorinated drinking water: effect of humic substances," Environmental Monitoring and Assessment, vol. 93, pp. 301-319, 2004.

[29] J. J. Rook, "Formation of haloforms during chlorination of natural waters," Journal of Water Treatment and Examination, vol. 23, pp. 234-243, 1974.

[30] W. Wang, B. Moe, J. Li, Y. Qian, Q. Zheng, and X-F. Li, "Analytical characterization, occurrence, transformation, and removal of the emerging disinfection byproducts halobenzoquinones in water," Trends in Analytical Chemistry. Part A, vol. 85, pp. 97$110,2016$.

[31] D. Zheng, R. C. Andrews, S. A. Andrews, and L. Taylor-Edmonds, "Effects of coagulation on the removal of natural organic matter, genotoxicity, and precursors to halogenated furanones," Water Research, vol. 70, pp. 118-129, 2015.

[32] S. D. Richardson, "Environmental mass spectrometry: emerging contaminants and current issues," Analytical Chemistry, vol. 84, no. 2, pp. 747-778, 2012.

[33] M. Serrano, I. Montesinos, M. J. Cardador, M. Silva, and M. Gallego, "Seasonal evaluation of the presence of 46 disinfection by-products throughout a drinking water treatment plant," Science of the Total Environment, vol. 517, pp. 246-258, 2015.

[34] USEPA., Controlling Disinfection By-Products And Microbial Contaminants in Drinking Water, EPA: 600-R-01-110, United States Environmental Protection Agency, 2013.

[35] USEPA., "National primary drinking water regulations: stage 2 disinfectants/disinfection byproducts rule fed," Regist, vol. 71, no. 2, pp. 387-493, 2006.

[36] S. Kumari, A. K. Biswas, and G. Gantam, "Succenturiate placenta: an incidental finding," Journal of Case Reports and Images in Obstetrics and Gynaecology, vol. 1, pp. 1-4, 2015.

[37] R. G. Tardiff, M. L. Carson, and M. E. Ginevan, "Updated weight of evidence for an association between adverse reproductive \& developmental effects and exposure to disinfection by-products (DBPs)," Regulatory Toxicology and Pharmacology, vol. 45, no. 2, pp. 185-205, 2006.

[38] M. Ince, D. Bashir, O. O. Oni et al., "Rapid assessment of drinking water quality in the Federal Republic of Nigeria: Country Report of the Pilot Project Implementation in 20042005," World Health Organization and UNICEF, 2010.

[39] "SON, Standard Organization of Nigeria, 2007. Nigerian Standard for Drinking Water Quality," Nigerian Industrial Standard NIS, vol. 554, p. 30p, 2007.

[40] M. Kehinde, Nationwide rapid water quality assessment program: progress report, Federal Ministry of Water Resources, Abuja, Nigeria, 2003.

[41] GuIdelines for Canadian Drinking Water Quality, Department of National Health and Welfare, Ottawa, Canada, 1978.

[42] WHO., Chloride in Drinking-Water: Guidelines for DrinkingWater Quality, World Health Organization, WHO, Geneva, Switzerland, 2003.

[43] M. J. Plewa and E. D. Wagner, "Charting a new path to resolve the adverse health effects of DBPs," in Recent Advances in Disinfection By-Products, ACS Symposium Series, Karanfil., T. Mitch, B. Westerhoff, P. Xie, Y., and Y. Xie, Eds., vol. 1190, American Chemical Society, Washington, DC, USA. 
[44] P. Roccaro, G. V. Korshin, D. Cook, C. W. K. Chow, and M. Drikas, "Effects of $\mathrm{pH}$ on the speciation coefficients in models of bromide influence on the formation of trihalomethanes and haloacetic acids," Water Research, vol. 62, pp. 117-126, 2014.

[45] J. Zhang, J. Yu, W. An et al., "Characterization of disinfection byproduct formation potential in 13 source waters in China," Journal of Environmental Sciences, vol. 23, pp. 183-188, 2011.

[46] B. Ye, W. Wang, L. Yang, and J. Wei, "Factors influencing disinfection by-products formation in drinking water of six cities in China," Journal of Hazardous Materials, vol. 171, pp. 147152, 2009.

[47] S. Chowdhury, M. J. Rodriguez, and R. Sadiq, "Disinfection byproducts in Canadian provinces: associated cancer risks and medical expenses," Journal of Hazardous Materials, vol. 187, no. 1-3, pp. 574-584, 2011.

[48] A. R. Pardakhti, G. R. N. Bidhendi, A. Torabian, A. Karbassi, and M. Yunesian, "Comparative cancer risk assessment of THMs in drinking water from well water sources and surface water sources," Environmental Monitoring and Assessment, vol. 179, no. 1-4, pp. 499-507, 2011.

[49] H. Amjad, I. Hashmi, M. S. U. Rehman, M. Ali Awan, S. Ghaffar, and Z. Khan, "Cancer and non-cancer risk assessment of trihalomethanes in urban drinking water supplies of Pakistan," Ecotoxicology and Environmental Safety, vol. 91, pp. 25-31, 2013.

[50] P. Charisiadis, S. S. Andra, K. C. Makris et al., "Spatial and seasonal variability of tap water disinfection by-products within distribution pipe networks," Science of the Total Environment, vol. 506-507, pp. 26-35, 2015.

[51] USEPA., "Drinking water guidance on disinfection by-products," in Advice Note No. 4. Version 2: Disinfection By-Products in Drinking Water, United States Environmental Protection Agency, 2012.

[52] N. S. Jakubovics, Biofilms in Potable Water Distribution Network [Ph.D. thesis], University of Warwick, University of Warwick Publications, 1998, http://webcast.warwick.ac.uk/36980.

[53] Guidelines for Drinking Water Quality, WHO, World Health Organization, Geneva, Switzerland, 2011.

[54] USEPA., 2012 Drinking Water Standards and Health Advisories tables, USEPA, United States Environmental Protection Agency, 2012, https://www.epa.gov/sites/production/files/2015-09/documents/dwstandards2012.pdf.

[55] World Bank., 2014. World Bank 2013 estimate for average life expectancy in Nigeria. World Bank Annual Report. Fiscal Year 2014 Regional Highlights.

[56] W. U. Anake, N. U. Benson, A. A. Akinsiku, C. O. Ehi-Eromosele, and I. O. Adeniyi, "Assessment of trace metals in drinking water and groundwater sources in Ota, Nigeria," International Journal of Scientific and Research Publications, vol. 4, no. 5, pp. $1-4,2014$. 


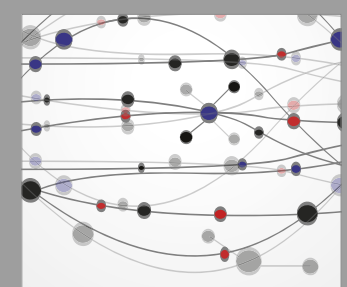

The Scientific World Journal
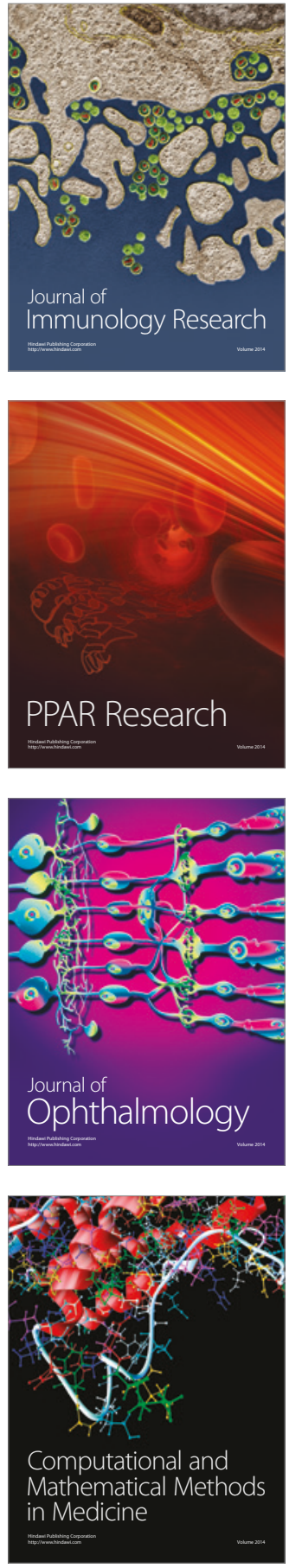

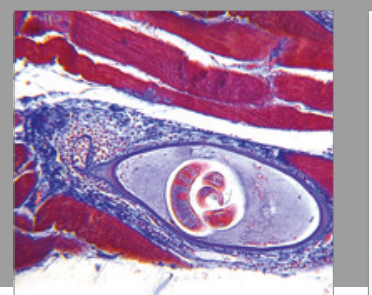

Gastroenterology Research and Practice
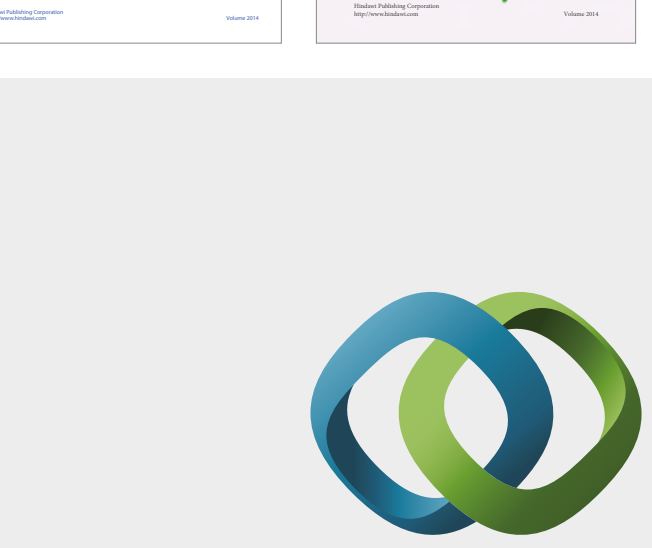

\section{Hindawi}

Submit your manuscripts at

https://www.hindawi.com
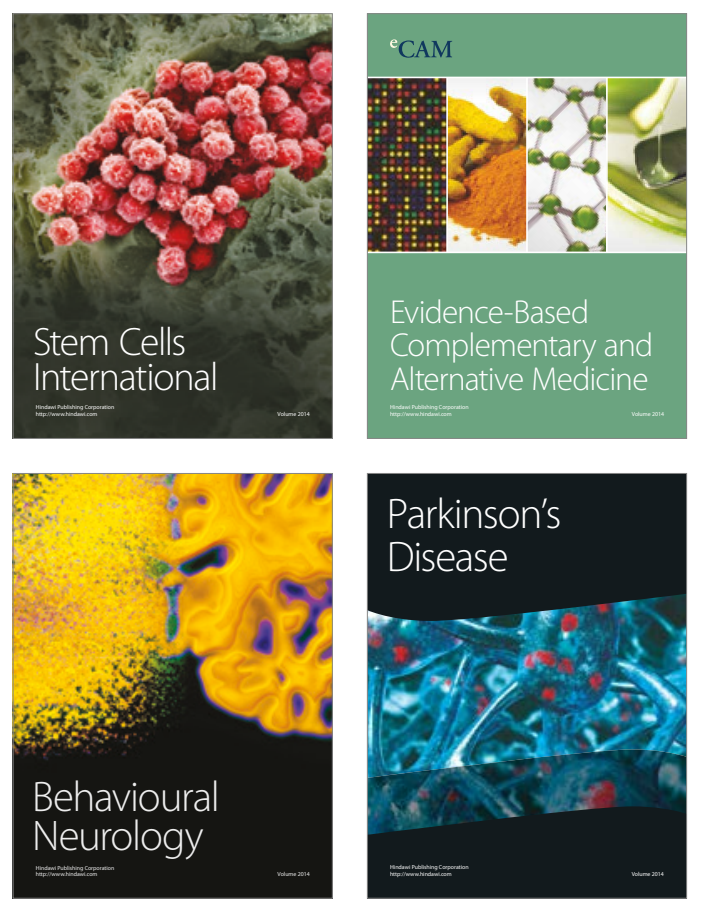
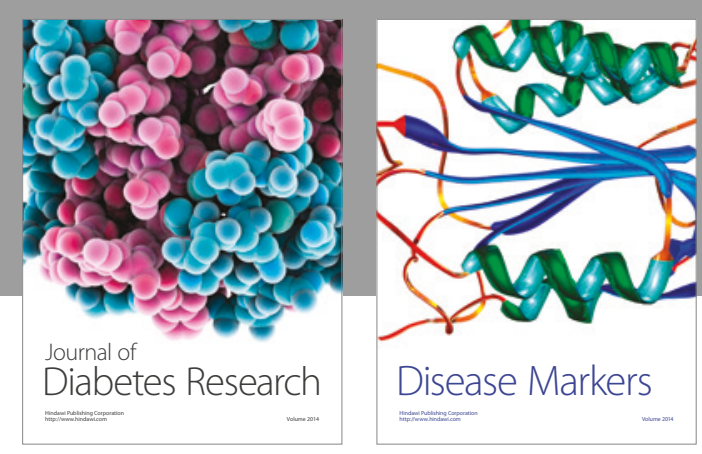

Disease Markers
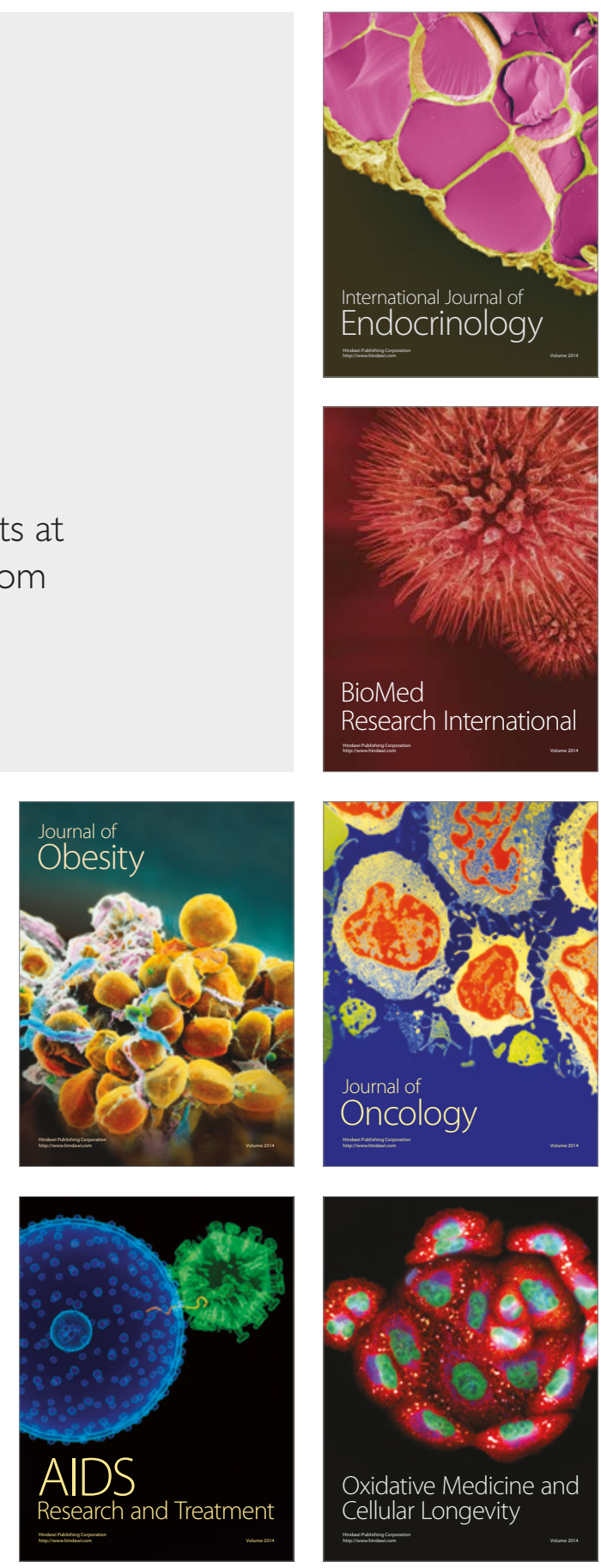